\title{
Fallow Reduces Soil Losses and Increases Carbon Stock in Caatinga
}

\author{
Cicero Lima de Almeida ${ }^{1}$, José Carlos de Araújo ${ }^{1}$, Mirian Cristina Gomes Costa ${ }^{2}$, \\ Aldênia Mendes Mascena de Almeida ${ }^{1}$, Eunice Maia de Andrade ${ }^{1}$ \\ ${ }^{1}$ Department of Agricultural Engineering, Universidade Federal do Ceará - UFC, Fortaleza/CE, Brazil \\ ${ }^{2}$ Department of Soil Science, Universidade Federal do Ceará - UFC, Fortaleza/CE, Brazil
}

\begin{abstract}
This study aimed at evaluating whether 10 years of fallow was sufficient to restore a degraded hillslope in the semi-arid Caatinga biome, Brazil. For this purpose, runoff, erosion, loss of nutrients and organic carbon were measured on two comparable hillslopes: one was left fallow and the other degraded caused by overgrazing. Fallow management reduced runoff (36\%), soil loss (65\%) and organic carbon loss (81\%) in comparison with the degraded hillslope. However, the fallow did not significantly reduce nutrient loss. Animal grazing has been shown to influence the nutrient cycle in the soil. The loss of organic carbon shows significant correlation with the loss of other nutrients, and may be used to estimate nutrient loss. Results show that a decade of fallow did not promote significant changes in the loss of nutrients, but was enough to reduce runoff, erosion and loss of organic carbon.
\end{abstract}

Keywords: soil recovery, land use, runoff, semi-arid. 


\section{INTRODUCTION AND OBJECTIVES}

In arid and semi-arid ecosystems, desertification is often associated with overgrazing ( $\mathrm{Li}$ et al., 2006; Navarro-Hevia et al., 2014; Kalema et al., 2015) because this process affects not only physical, chemical and biological properties of the soil, but also the vegetation composition and coverage (Kurz et al., 2005; Brazier et al., 2014; Palacio et al., 2014). Environmental degradation of dry areas directly affects the social development of the surrounding region due to reduced water availability as well as food and energy production, leading to more severe social vulnerability and socioeconomic conflicts (Döll et al., 2015). Research studies have shown that livestock, one of the most important economic activities in the rural Caatinga (Nunes et al., 2014), effectively contributes to cycling of soil nutrients (Van Beek et al., 2009; Ebeledike et al., 2010; Sath et al., 2012; Lessa et al., 2014).

In cultivated and grazed areas, fallow is the oldest and least expensive land management practice for promoting environmental recovery and regeneration of vegetation, soil and fauna over the long term (Sousa et al., 2012; Mekuria \& Aynekulu, 2013; Costantini et al., 2016). This management consists of reclamation of degraded land by means of resilience of the soil and vegetation alone. The main indicators used to assess the restoration of a given area are organic matter, physical and chemical characteristics of the soil, water infiltration, soil and nutrient loss, soil compaction, vegetation, and patterns of succession in different semi-arid regions of the world (Manzano \& Návar, 2000; Costantini et al., 2016; Tang et al., 2016). In the Brazilian semi-arid region, studies in degraded areas usually focus on soil loss and runoff (Medeiros \& Araújo, 2014), but there are few studies reporting nutrient transportation (Freitas et al., 2013) and the necessary time period for soil restoration in degraded areas of Caatinga (Sousa et al., 2012). The Brazilian semi-arid region through which the Caatinga biome dominates consists of approximately $840,000 \mathrm{~km}^{2}$ $(10 \%)$ of the area of the country. This biome has a mix of deep and shallow soils with a high potential for salinization; highly spatiotemporal variable rainfall; and xerophytic and caduceus vegetation (Silva et al., 2014). This combination of features makes Caatinga vulnerable to anthropogenic activity, leaving it prone to desertification (Menezes et al., 2012; Fernandes et al.,
2015). The aim of this study was to evaluate the effects of 10 years of fallow on the impacts of previous long-term soil degradation in the semi-arid region of Brazil. For this purpose, differences in runoff, erosion, and the loss of organic carbon and nutrients were assessed on two hillslopes with similar area, climate, soil and topography, differing only in use and coverage of the land.

\section{MATERIALS AND METHODS}

The experimental site was located in the desertification area of Irauçuba, in the Brazilian state of Ceará $\left(3.77^{\circ} \mathrm{S} ; 39.83^{\circ} \mathrm{W}\right)$. The study period encompassed two hydrological years (2010 and 2011). The climate, according to the Köppen classification, is BSw'h' (hot and semi-arid grassland) with rainfall concentrated in the period from February to March. The annual average precipitation is $446 \mathrm{~mm} \mathrm{yr}^{-1}(1981-2015)$ and the potential evapotranspiration is $2,000 \mathrm{~mm} \mathrm{yr}^{-1}$ for Irauçuba. The average relative humidity is $68 \%$, the average annual temperature is $27^{\circ} \mathrm{C}$ and the average annual insolation is $2,520 \mathrm{~h}$ (INMET, 2016). The soil in the study area is Haplic Solonetz with flat terrain. Two hillslopes were selected: one degraded $\left(\mathrm{H}_{\mathrm{D}}\right)$ and one under recovery $\left(\mathrm{H}_{\mathrm{F}}\right)$ that had been degraded to the same extent as $\mathrm{H}_{\mathrm{D}}$, but left free from agricultural activity for ten years, i.e. lying fallow (Figure 1).

The total area of $\mathrm{H}_{\mathrm{F}}$ comprises $370 \mathrm{~m}^{2}$, with average gradient of $0.029 \mathrm{~m} \mathrm{~m}^{-1}$ and elevation of $156 \mathrm{~m}$. The total area of $\mathrm{H}_{\mathrm{D}}$ comprises $468 \mathrm{~m}^{2}$, with average gradient of $0.034 \mathrm{~m} \mathrm{~m}^{-1}$ and elevation of $155 \mathrm{~m}$. Land use is characterised by overgrazing (cattle, sheep and horses throughout the year) for over 20 years with no conservation practices (Sousa et al., 2012). The hillslopes are located $200 \mathrm{~m}$ apart from each other and both share the same soil, landscape and climate conditions. In the rainy season of 2010, soil samples were collected from the experimental site at depths of $0-0.2 \mathrm{~m}$ and $0.2-0.4 \mathrm{~m}$ for chemical and physical characterization (Table 1).

Throughout the period of study, only 20 rainfall events generated runoffs, but analysis was restricted to 11 events, when data on rainfall and runoff were collected, as well as data on soil, organic carbon and nutrient loss. Daily Precipitation (DP) was monitored by two Ville de Paris rain gauges, one on each hillslope. Also, accumulated rainfall for the previous five days 


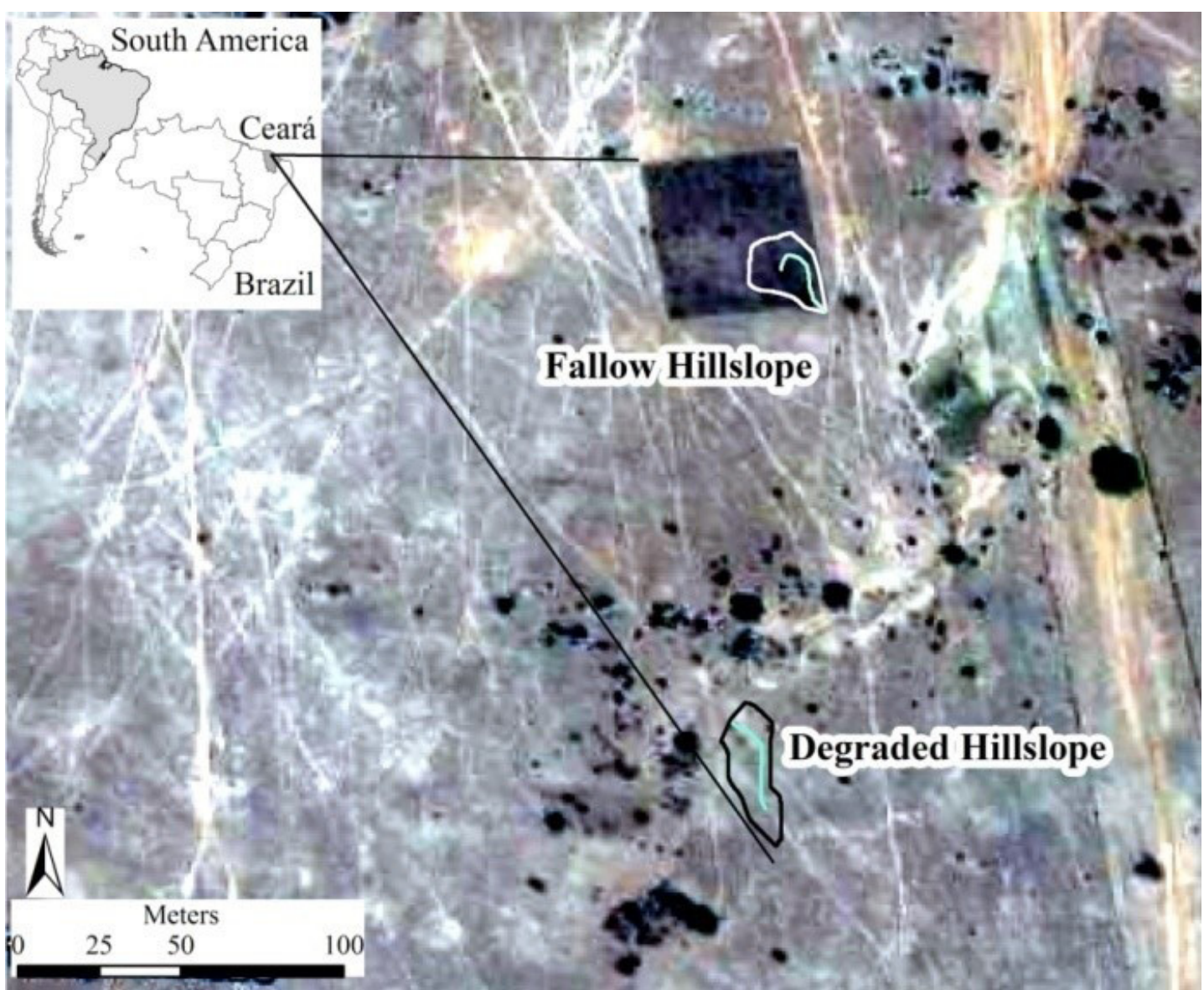

Figure 1. Map of the localization of the experimental site, Irauçuba Ceará, Brazil.

(DP.ac) was registered as an indirect way of estimating antecedent soil moisture. Runoff $(\mathrm{R})$ and soil loss $(\Delta S)$ after each event were monitored by means of a collection system installed at the outlet of each slope, consisting of two boxes (adapted from Wischmeier \& Smith, 1978). The first box had 10 hydraulically similar holes, one of which was connected to the second collection box. The water discharge flowed into the first box. In case the box filled up, water and sediment would overflow into the second box. For each hillslope, the runoff volume was registered and samples of water and suspended sediment were collected immediately after the end of each runoff event. Runoff (R) was calculated using Equations 1a, 1b, whereas soil loss $\Delta S$ was calculated with Equations $2 \mathrm{a}, 2 \mathrm{~b}$, substituting the concentration of the generic constituent $\varphi$ by the sediment concentration, obtained by drying at $105^{\circ} \mathrm{C}$ to constant weight.

$R=V_{1} / A ;$ if $V_{2}=0$
$R=\left(V_{1}+10 \times V_{2}\right) / A ;$ if $V_{2}>0$

$\Delta \phi=V_{1} \times S_{\phi 1} / A ;$ if $V_{2}=0$

$\Delta \phi=\left(V_{1} \times S_{\phi 1}+10 \times V_{2} \times S_{\phi 2}\right) / A ;$ if $V_{2}>0$

Variables ' $V_{1}$ ' and ' $V_{2}$ ' are the volumes of water in boxes 1 and 2 respectively; ' $A$ ' is the hillslope catchment area; $\Delta \phi$ is the constituent loss (soil, carbon or nutrient) and ' $S_{\phi 1}$ ' and ' $S_{\phi 2}$ ' are the concentrations of the generic constituent $\phi$ in boxes 1 and 2 respectively.

The total organic carbon $(\triangle \mathrm{OC})$ and the total nutrient loss (total nitrogen $(\Delta \mathrm{N})$, total phosphorus $(\Delta \mathrm{P})$, potassium $(\Delta \mathrm{K})$, calcium $(\Delta \mathrm{Ca})$ and sodium $(\Delta \mathrm{Na}))$ in the samples of water and suspended sediments for each runoff event were assessed by Equations 2a, $2 \mathrm{~b}$. This was done by replacing the concentration of each element by $\phi$. Organic carbon was estimated by burning the sediment in a muffle furnace at $500{ }^{\circ} \mathrm{C}$ for $20 \mathrm{~min}$. Total nitrogen was determined by potassium 
Table 1. Chemical and physical attributes of the soil on both fallow $\left(\mathrm{H}_{\mathrm{F}}\right)$ and degraded $\left(\mathrm{H}_{\mathrm{D}}\right)$ hillslopes, Irauçuba, Ceará, April 2010.

\begin{tabular}{|c|c|c|c|c|c|}
\hline \multirow{2}{*}{ Characteristic } & \multirow{2}{*}{ Unit } & \multicolumn{2}{|c|}{$\mathbf{H}_{\mathrm{F}}$} & \multicolumn{2}{|c|}{$\mathrm{H}_{\mathrm{D}}$} \\
\hline & & $0.0-0.2 \mathrm{~m}$ & $0.2-0.4 \mathrm{~m}$ & $0.0-0.2 \mathrm{~m}$ & $0.2-0.4 \mathrm{~m}$ \\
\hline $\mathrm{pH}_{\mathrm{H} 2 \mathrm{O}}^{1}$ & - & 5.7 & 6.3 & 6.2 & 6.8 \\
\hline Organic carbon $(\mathrm{OC})^{2}$ & $\mathrm{~g} \mathrm{~kg}^{-1}$ & 5.7 & 2.8 & 4.7 & 2.8 \\
\hline Nitrogen $(\mathrm{N})^{3}$ & $\mathrm{~g} \mathrm{~kg}^{-1}$ & 0.5 & 0.2 & 0.5 & 0.3 \\
\hline Available phosphorus $(\mathrm{P})^{4}$ & $\mathrm{mg} \mathrm{kg}{ }^{-1}$ & 15 & 18 & 141 & 73 \\
\hline Potassium $\left(\mathrm{K}^{+}\right)^{4}$ & \multirow{7}{*}{$\mathrm{cmol}_{\mathrm{c}} \mathrm{kg}^{-1}$} & 0.2 & 0.1 & 0.2 & 0.1 \\
\hline Calcium $\left(\mathrm{Ca}^{2+}\right)^{5}$ & & 4.0 & 12.0 & 6.8 & 9.5 \\
\hline Magnesium $\left(\mathrm{Mg}^{2+}\right)^{5}$ & & 2.0 & 5.5 & 6.5 & 8.8 \\
\hline Aluminium $\left(\mathrm{Al}^{3+}\right)^{5}$ & & 0.6 & 0.3 & 0.3 & 0.3 \\
\hline Sodium $\left(\mathrm{Na}^{+}\right)^{6}$ & & 0.4 & 2.5 & 0.3 & 1.4 \\
\hline Sum of bases $(\mathrm{SB})^{7}$ & & 6.5 & 20.1 & 13.8 & 19.8 \\
\hline $\mathrm{CEC}^{7}$ & & 8.7 & 20.9 & 15.3 & 20.6 \\
\hline Base saturation $(\mathrm{V})^{7}$ & \multirow{3}{*}{$\%$} & 75 & 96 & 90 & 96 \\
\hline Aluminum saturation $(\mathrm{m})^{7}$ & & 8 & 1 & 2 & 1 \\
\hline $\mathrm{ESP}^{7}$ & & 4 & 12 & 2 & 7 \\
\hline Sand $^{7,8}$ & \multirow{3}{*}{$\mathrm{g} \mathrm{kg}^{-1}$} & 714 & 488 & 662 & 554 \\
\hline Silt $^{7,8}$ & & 193 & 214 & 203 & 224 \\
\hline $\mathrm{Clay}^{7,8}$ & & 93 & 298 & 135 & 222 \\
\hline Texture & - & Sandy loam & $\begin{array}{l}\text { Sandy clay } \\
\text { Loam }\end{array}$ & Sandy loam & $\begin{array}{c}\text { Sandy clay } \\
\text { loam }\end{array}$ \\
\hline
\end{tabular}

${ }^{1}$ 1:2.5 soil:water; ${ }^{2}$ Yeomans \& Bremner (1988); ${ }^{3}$ Kjeldahl method; ${ }^{4} \mathrm{P}$ and $\mathrm{K}$ by Mehlich extraction; ${ }^{5} \mathrm{Ca}$, $\mathrm{Mg}$, and $\mathrm{Al}$ by $\mathrm{KCl}$ extraction; ${ }^{6} \mathrm{Na}$ in the saturation extract; ${ }^{7}$ Calculation as per EMBRAPA (1997); ${ }^{8}$ Pipette method. ESP - Exchangeable sodium percentage; CEC - Cation exchange capacity.

persulfate $\left(\mathrm{K}_{2} \mathrm{~S}_{2} \mathrm{O}_{8}\right)$ digestion, followed by reduction in a cadmium column. Total phosphorus was determined by ammonium persulfate $\left[\left(\mathrm{NH}_{4}\right)_{2} \mathrm{~S}_{2} \mathrm{O}_{8}\right]$ digestion, followed by ascorbic acid $\left(\mathrm{C}_{6} \mathrm{H}_{8} \mathrm{O}_{6}\right)$ colorimetry (APHA, 2005). The elements $\mathrm{K}$ and $\mathrm{Na}$ were extracted employing Mehlich 1, with subsequent quantification by flame photometry. Calcium was extracted with $\mathrm{KCl}$ and also quantified by flame photometry (EMBRAPA, 1997).

Shapiro-Wilk tests $(\rho>0.05)$ showed that data of $\mathrm{R}$, and $\triangle \mathrm{S}, \triangle \mathrm{OC}$ and nutrient losses for the two slopes did not have normal distribution. This data were, therefore, subjected to Mann-Whitney U test $(\rho<0.10)$ to compare means. Data of DP and DP.ac were subjected to T-test $(\rho>0.05)$ for comparison of means, as they showed normal distribution. Spearman correlation analysis $(\rho>0.05)$ was carried out between $\triangle \mathrm{OC}$ and nutrient loss to check whether organic matter is the main source of nutrients. Cluster analysis was used to verify similarities between the variables of the two slopes. Data were standardized using the method of Z-scores. Definition of the number of clusters took place when the rescaled distance of the clustering coefficient showed the greatest variation. Similarity was measured by squared Euclidean distance. The applied clustering algorithm was the Ward method. The analysis was performed using the SPSS 16.0 software.

\section{RESULTS}

Table 2 shows a summary of precipitation and runoff, as well as soil, organic carbon and nutrient losses for both hillslopes in the events evaluated. As expected, precipitation data from both rain gauges showed no statistical difference due to the proximity between the instruments. However, runoff, $\Delta S$ and $\Delta \mathrm{OC}$ were significantly different between hillslopes $(\rho<0.10)$. A decade of fallow at Irauçuba site caused a reduction in $\mathrm{R}$ of $36 \%$, which means that more water was retained on site, raising the loss by potential 
Table 2. Cumulative total of the respective variable for the analysis events (total), average and standard deviation $(\mu \pm S D)$, average suspended concentration of sediment, organic carbon and nutrients (SC), test of normality and mean comparison test $(\mathrm{MCT})$ for the variables of the fallow hillslope $\left(\mathrm{H}_{\mathrm{F}}\right)$ and degraded hillslope $\left(\mathrm{H}_{\mathrm{D}}\right)$. Irauçuba, Ceará (2010-2011). $\mathrm{N}$ is the number of events.

\begin{tabular}{|c|c|c|c|c|c|c|}
\hline Variable & $\begin{array}{l}\text { Hillslope } \\
(\mathbf{N})\end{array}$ & Total & $\mu \pm \mathrm{SD}$ & $\begin{array}{c}\mathrm{SC} \\
\left(\mathrm{mg} \mathrm{L}^{-1}\right)\end{array}$ & Shapiro-Wilk & $\operatorname{MCT}(\rho)$ \\
\hline \multirow{2}{*}{$\begin{array}{l}\text { Daily precipitation } \\
(\mathrm{mm}) \mathrm{DP}\end{array}$} & $\mathrm{H}_{\mathrm{F}}(11)$ & 227 & $20.7 \pm 10.8$ & n.a. & 0.413 & \multirow{2}{*}{$0.902^{1}$} \\
\hline & $\mathrm{H}_{\mathrm{D}}(11)$ & 221 & $20.1 \pm 10.3$ & n.a. & 0.659 & \\
\hline \multirow{2}{*}{$\begin{array}{l}\text { Accumulated rainfall } \\
\text { over } 5 \text { days }(\mathrm{mm}) \mathrm{DPac}\end{array}$} & $\mathrm{H}_{\mathrm{F}}(11)$ & 237 & $21.5 \pm 14.6$ & n.a. & 0.357 & \multirow{2}{*}{$0.949^{1}$} \\
\hline & $\mathrm{H}_{\mathrm{D}}(11)$ & 233 & $21.1 \pm 14.6$ & n.a. & 0.355 & \\
\hline \multirow{2}{*}{ Runoff (mm) R } & $\mathrm{H}_{\mathrm{F}}(11)$ & 32 & $2.9 \pm 6.3$ & n.a. & 0.000 & \multirow{2}{*}{0.071} \\
\hline & $\mathrm{H}_{\mathrm{D}}(11)$ & 50 & $4.6 \pm 7.4$ & n.a. & 0.007 & \\
\hline \multirow{2}{*}{ Soil loss $\left(\mathrm{kg} \mathrm{ha}^{-1}\right) \Delta \mathrm{S}$} & $\mathrm{H}_{\mathrm{F}}(11)$ & 158 & $14.4 \pm 29.7$ & 682 & 0.001 & \multirow{2}{*}{0.071} \\
\hline & $\mathrm{H}_{\mathrm{D}}(11)$ & 457 & $41.5 \pm 50.2$ & 1199 & 0.002 & \\
\hline \multirow{2}{*}{$\begin{array}{l}\text { Organic carbon loss } \\
\left(\mathrm{kg} \mathrm{ha}^{-1}\right) \Delta \mathrm{OC}\end{array}$} & $\mathrm{H}_{\mathrm{F}}(9)$ & 10 & $1.1 \pm 1.3$ & 250.5 & 0.010 & \multirow{2}{*}{0.058} \\
\hline & $\mathrm{H}_{\mathrm{D}}(9)$ & 54 & $6.0 \pm 6.8$ & 328.9 & 0.051 & \\
\hline \multirow{2}{*}{$\begin{array}{l}\text { Nitrogen loss }\left(\mathrm{g} \mathrm{ha}^{-1}\right) \\
\Delta \mathrm{N}\end{array}$} & $\mathrm{H}_{\mathrm{F}}(11)$ & 61 & $5.5 \pm 5.7$ & 0.51 & 0.004 & \multirow{2}{*}{0.224} \\
\hline & $\mathrm{H}_{\mathrm{D}}(11)$ & 241 & $21.9 \pm 30.7$ & 0.68 & 0.000 & \\
\hline \multirow{2}{*}{$\begin{array}{l}\text { Phosphorus loss }\left(\mathrm{g} \mathrm{ha}^{-1}\right) \\
\Delta \mathrm{P}\end{array}$} & $\mathrm{H}_{\mathrm{F}}(11)$ & 45 & $4.1 \pm 5.0$ & 0.33 & 0.001 & \multirow{2}{*}{0.158} \\
\hline & $\mathrm{H}_{\mathrm{D}}(11)$ & 165 & $15.0 \pm 22.2$ & 0.46 & 0.000 & \\
\hline \multirow{2}{*}{$\begin{array}{l}\text { Sodium loss }\left(\mathrm{g} \mathrm{ha}^{-1}\right) \\
\Delta \mathrm{Na}\end{array}$} & $\mathrm{H}_{\mathrm{F}}(11)$ & 4,103 & $373 \pm 392$ & 38.27 & 0.001 & \multirow{2}{*}{0.341} \\
\hline & $\mathrm{H}_{\mathrm{D}}(11)$ & 7,621 & $693 \pm 748$ & 25.59 & 0.002 & \\
\hline \multirow{2}{*}{$\begin{array}{l}\text { Potassium loss }\left(\mathrm{g} \mathrm{ha}^{-1}\right) \\
\Delta \mathrm{K}\end{array}$} & $\mathrm{H}_{\mathrm{F}}(11)$ & 2,980 & $271 \pm 265$ & 33.45 & 0.005 & \multirow{2}{*}{0.279} \\
\hline & $\mathrm{H}_{\mathrm{D}}(11)$ & 4,544 & $413 \pm 359$ & 25.23 & 0.017 & \\
\hline \multirow{2}{*}{$\begin{array}{l}\text { Calcium loss }\left(\mathrm{g} \mathrm{ha}^{-1}\right) \\
\Delta \mathrm{Ca}\end{array}$} & $\mathrm{H}_{\mathrm{F}}(11)$ & 232 & $21.1 \pm 30.4$ & 4.18 & 0.001 & \multirow{2}{*}{0.151} \\
\hline & $\mathrm{H}_{\mathrm{D}}(11)$ & 78 & $7.1 \pm 12.2$ & 0.83 & 0.000 & \\
\hline
\end{tabular}

${ }^{1}$ Analyses performed based on the T-test; the remaining analyses were performed based on the Mann-Whitney U test. n.a. not applicable.

infiltration and improving plant growth. Fallow also caused a considerable reduction in erosion $(\Delta \mathrm{S}$ was reduced by $65 \%)$, and greater retention of organic carbon ( $\triangle \mathrm{OC}$ was reduced by $81 \%)$.

The period of fallow caused a general decline in terms of nutrient loss: 75\% for nitrogen, 73\% for phosphorous, and $34 \%$ for potassium. Furthermore, a reduction of $46 \%$ for sodium was observed. In contrast, calcium loss increased three-fold. The comparison of means, however, showed no significant difference $(\rho>0.10)$ of nutrient loss between hillslopes, although $\mathrm{H}_{\mathrm{D}}$ had values up to four times greater than those observed for $\mathrm{H}_{\mathrm{F}}$ (Table 2). As for characterization of soil of each hillslope (Table 1), differences could be seen in the levels of $\mathrm{P}, \mathrm{Mg}$ and $\mathrm{Ca}$ at 0 to $20 \mathrm{~cm}$ depths; these are approximately 10, 3 and 1.5 times greater, respectively, for $\mathrm{H}_{\mathrm{D}}$ compared to $\mathrm{H}_{\mathrm{F}}$.

Table 3 shows the correlation between nutrient and organic carbon losses on both hillslopes at the
Table 3. Spearman correlation between organic carbon loss $(\triangle \mathrm{OC})$ and nutrient losses for the fallow hillslope $\left(\mathrm{H}_{\mathrm{F}}\right)$ and the degraded hillslope $\left(\mathrm{H}_{\mathrm{D}}\right)$, Irauçuba Ceará, 2010-2011.

\begin{tabular}{lccccc}
\multirow{2}{*}{ Nutrients loss } & \multicolumn{2}{c}{$\mathbf{H}_{\mathrm{D}}$} & & \multicolumn{2}{c}{$\mathbf{H}_{\mathrm{F}}$} \\
\cline { 2 - 3 } \cline { 6 - 6 } & $\mathbf{R}$ & $\boldsymbol{\rho}$ & & $\mathbf{R}$ & $\boldsymbol{\rho}$ \\
\hline Nitrogen loss $-\Delta \mathrm{N}$ & 0.767 & 0.016 & & 0.883 & 0.005 \\
Phosphorus loss $-\Delta \mathrm{P}$ & 0.717 & 0.030 & & 0.750 & 0.020 \\
\hline Sodium loss $-\Delta \mathrm{Na}$ & 0.750 & 0.020 & & 0.950 & 0.000 \\
\hline Potassium loss $-\Delta \mathrm{K}$ & 0.783 & 0.013 & & 0.917 & 0.001 \\
\hline Calcium loss $-\Delta \mathrm{Ca}$ & 0.176 & 0.651 & & 0.268 & 0.486 \\
\hline
\end{tabular}

Irauçuba site. It can be seen that the losses of nutrients $(\mathrm{N}, \mathrm{P}$ and $\mathrm{K})$, besides $\mathrm{Na}$, were positively $(\mathrm{r}>0)$ and significantly $(\rho<0.05)$ correlated with loss of organic carbon in both hillslopes. However, $\Delta \mathrm{Ca}$ did not correlate with the loss of carbon in either of the areas studied.

Cluster analysis results for the variables of the two hillslopes can be seen in the dendrogram (Figure 2). At the point of analysis (distance 7), four groups were 


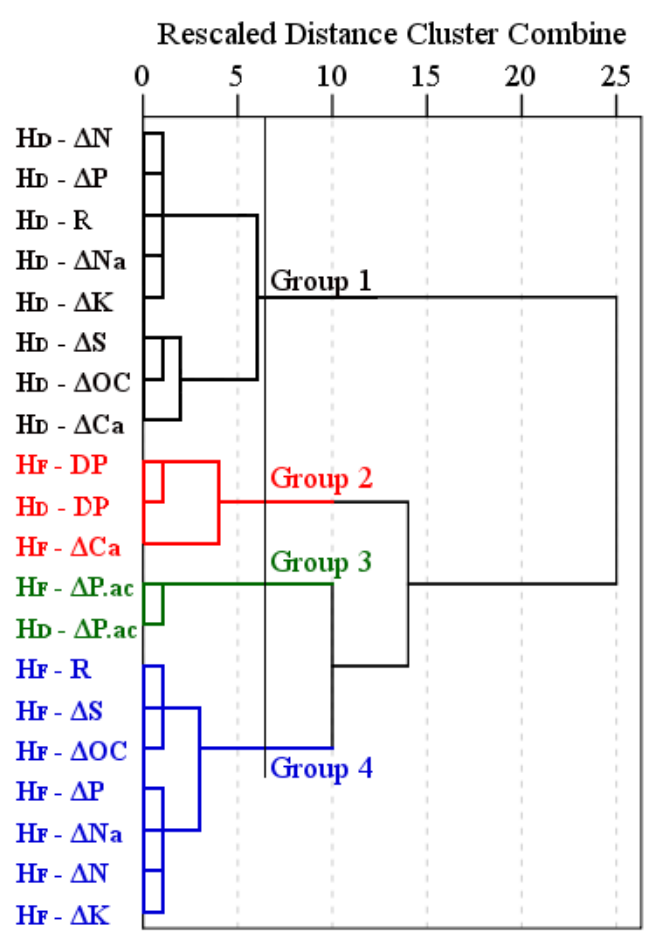

Figure 2. Dendrogram of the attributes analysed for two hill slopes, Irauçuba Ceará, 2010 - 2011. $\mathrm{H}_{\mathrm{F}}=$ fallow hillslope; $\mathrm{H}_{\mathrm{D}}=$ degraded hillslope; $\mathrm{DP}=$ daily precipitation $(\mathrm{mm}) ; \mathrm{DP} . \mathrm{ac}=$ accumulated rainfall over 5 days $(\mathrm{mm}) ; \mathrm{R}=\operatorname{runoff}(\mathrm{mm}) ; \Delta \mathrm{S}=$ soil loss $\left(\mathrm{kg} \mathrm{ha}^{-1}\right) ; \Delta \mathrm{OC}=$ organic carbon loss $\left(\mathrm{kg} \mathrm{ha}^{-1}\right)$; $\Delta \mathrm{N}=$ nitrogen loss $\left(\mathrm{g} \mathrm{ha}^{-1}\right) ; \Delta \mathrm{P}=$ phosphorus loss $\left(\mathrm{g} \mathrm{ha}^{-1}\right) ; \Delta \mathrm{Na}=$ sodium loss $\left(\mathrm{g} \mathrm{ha}^{-1}\right) ; \Delta \mathrm{K}=$ potassium loss $\left(\mathrm{g} \mathrm{ha}^{-1}\right) ; \Delta \mathrm{Ca}=$ calcium loss $\left(\mathrm{g} \mathrm{ha}^{-1}\right)$.

formed. Group 2 is related to the calcium eroded by $\mathrm{H}_{\mathrm{p}}$, whereas Group 3 is formed by the independent variables (DP and DP.ac). Groups 1 and 4 are made up of variables for $\mathrm{H}_{\mathrm{D}}$ and $\mathrm{H}_{\mathrm{F}}$ (runoff, and soil and nutrient loss), respectively. The dendrogram shows that group 4 (composed of variables from the $\mathrm{H}_{\mathrm{F}}$ ) presented greater similarity (formed at distance 3 ), i.e., this group was more homogeneous than group 1 (formed at distance 6), which is composed of elements from the $\mathrm{H}_{\mathrm{D}}$.

\section{DISCUSSION}

Ten years of fallow has reduced runoffs as well as soil and organic carbon losses in $\mathrm{H}_{\mathrm{F}}$ According to the statistical analysis $(\rho<0.10$, Table 2$)$, runoffs and soil losses were smaller in $\mathrm{H}_{\mathrm{F}}$ than in $\mathrm{H}_{\mathrm{D}}$. Studies such as those of El Kateb et al. (2013), Mekuria \& Aynekulu (2013), Freitas et al. (2013) and Brazier et al. (2014) point to land cover as the main factor to reduce $\mathrm{R}$ and $\Delta S$. In line with these results, Trabaquini et al. (2015) showed that land degradation (1980-2010) in Brazilian savannah (Cerrado) has altered the soil's physical attributes, increasing runoff; bulk density and penetration resistance, whereas air permeability and porosity decreased.

Table 2 also shows that $\triangle \mathrm{OC}$ values were smaller in $\mathrm{H}_{\mathrm{F}}$ due to reduced runoff in consequence of denser ground cover. Tang et al. (2016) observed that areas with larger aboveground biomass have higher aggregate stability which has correlation with erosion-related variables, especially soil erodibility (Stanchi et al., 2016). The observed reduction of $\triangle O C$ and increased land cover may be an indication of an increase in the carbon stock in $\mathrm{H}_{\mathrm{F}}$, which improved soil's physical conditions such as aggregate stability, infiltration, porosity and water storage capacity (Stanchi et al., 2016; Costantini et al., 2016).

The correlation observed between $\triangle \mathrm{OC}$ and nutrient loss in both hillslopes gives evidence that organic waste (Menezes et al., 2012), which is easily transported by erosion, is one of factor responsible for nutrient cycling. The loss of this fundamental organic material to soil structure causes lower stability in the aggregates (Tang et al., 2016), facilitating higher rates of erosion and contributing to the eutrophication of lakes and rivers by nutrient transportation, particularly of phosphorus and nitrogen (Kurz et al., 2005; Li et al., 2006). This correlation was also observed by Li et al. (2006). Results show that organic carbon proved to be a good parameter to evaluate the loss of nutrients on both hillslopes.

Statistical tests showed no significant differences $(\rho<0.10)$ for $\Delta \mathrm{N}, \Delta \mathrm{Na}, \Delta \mathrm{K}, \Delta \mathrm{P}$ or $\Delta \mathrm{Ca}$. This indicates that the period of fallow, despite having promoted an improvement in some $(\Delta S, R$ and $\Delta$ OCbut not all soil variables. This may be related to the time needed for restoration of biogeochemical cycles in the fallow area (Navarro-Hevia et al., 2014) or to the high coefficient of variation, mainly in $\mathrm{H}_{\mathrm{D}}$ (SD $1.5>\mathrm{H}_{\mathrm{P}}$, see Table 2), which was probably caused by the input from animal excrement, less ground cover (see Figure 1), and the small number of events (eleven) (Manzano \& Návar, 2000). The frequency of events with runoff in Caatinga 
is considerably low (Medeiros \& Araújo, 2014) and this makes hydrological investigations in the region more difficult.

Increased organic carbon and nutrients in the soil due to animal droppings in grazing areas has been reported in other studies (Kurz et al., 2005; Lessa et al., 2014), as well as decreased ground cover by overgrazing (Mekuria \& Aynekulu, 2013; Palacio et al., 2014). This contributes to increasing the magnitude of the processes in $\mathrm{H}_{\mathrm{D}}$. However, studies have found that the time analyzed was not enough to allow the recovery of degraded lands (Manzano \& Návar, 2000). Fallow is only effective on the long term (Costantini et al., 2016). According to Príncipe et al. (2014), a period of at least 30 years is necessary for natural forests regenerate in semi-arid areas.

Soil characterization of each hillslope (Table 1) showed higher levels of $\mathrm{P}, \mathrm{Mg}$ and $\mathrm{Ca}$ at $0-20 \mathrm{~cm}$ depth in $\mathrm{H}_{\mathrm{D}}$ in comparison to $\mathrm{H}_{\mathrm{F}}$. This is most likely due to the presence of animals in the $H_{D}$. However, it is important to note that $H_{D}$ is more susceptible to erosion and loss of the above mentioned nutrients. One evidence of the erosion in $\mathrm{H}_{\mathrm{D}}$ is the texture of the surface horizon that has $40 \mathrm{~g} \mathrm{~kg}^{-1}$ more clay than $\mathrm{H}_{\mathrm{F}}$ This results from the partial removal of the A horizon in the overgrazed area causing the natric B horizon (richer in clay) to appear at depths of less than $20 \mathrm{~cm}$ (Sousa et al., 2012). Furthermore, the smaller area of covered ground (Figure 1) provides less protection against soil erosion (Brazier et al., 2014; El Kateb et al., 2013; Freitas et al., 2013; Fernandes et al., 2015).

The high values of $\mathrm{P}$ in soil (Table 1 ) and of $\mathrm{P}$ lost (Table 2) in $H_{D}$ were enhanced by animal droppings, which also made the loss of these nutrients possible through erosion. It is assumed that a part of the nutrients are retained in the plants and/or immobilized in the soil in $\mathrm{H}_{\mathrm{F}}$ due to vegetation growth and formation of mulch. Kurz et al. (2005) noted that after grazing, the concentration of phosphorus in the runoff was greater as a consequence of the high amount of such nutrient added to the soil from animal droppings. This, in turn, increases the potential of loss through runoff. Ebeledike et al. (2010), Sath et al. (2012) and Lessa et al. (2014) reported that the amount of nutrients released by animal faeces and urine depends on the type of animal and its diet.
Despite the lack of significant different $\Delta$ Ca between hillslopes, this was the only element whose values were higher in $\mathrm{H}_{\mathrm{F}}$ than in $\mathrm{H}_{\mathrm{D}}$. This result is confirmed by the concentrations of $\mathrm{Ca}$ in suspended sediment, which was six times higher from $\mathrm{H}_{\mathrm{F}}$ than from $\mathrm{H}_{\mathrm{D}}$ (Table 2). The greater $\Delta \mathrm{Ca}$ in $\mathrm{H}_{\mathrm{F}}$ is probably due to cycling of this nutrient in this area. As calcium is a constituent of plant cell walls, this element must have accumulated in the vegetation that was growing on $\mathrm{H}_{\mathrm{F}}$ during the fallow period. Besides herbaceous species, $\mathrm{H}_{\mathrm{F}}$ also has theshrub-like species Mimosa hostiles, which, according to Araújo \& Costa (2013), accumulates large amounts of calcium in its tissue. The plant's litter has high calcium content and releases considerable amounts of this nutrient in the soil solution when the plant is decomposed (Zhao et al., 2014), thereby increasing losses. However $\mathrm{H}_{\mathrm{D}}$ was not favoured by this dynamic because, besides the absence of Mimosa hostiles, animals continually consume the vegetation, incorporating into their bone structure and milk most of the Ca accumulated in the plants (Ebeledike et al., 2010). The concentrations of $\mathrm{Na}$ and $\mathrm{K}$ in the runoff in $\mathrm{H}_{\mathrm{F}}$ are also due to greater amounts of these elements in plant debris from the species that developed on the fallow area (Amorim et al., 2014). Because these elements are not bound as compounds in the plant tissue, they are easily released into the soil solution by decomposition, making them susceptible to loss through runoff (Araújo \& Costa, 2013).

The largest loss was seen in the case of $\mathrm{Na}$, followed by $\mathrm{K}$, in both hillslopes (Table 2). The loss of $\mathrm{Na}$ transported by water erosion is explained by the class of soil, Haplic Solonetz, which has a horizon where exchangeable sodium just below the $\mathrm{A}$ and/or $\mathrm{E}$ horizon accumulates (Sousa et al., 2012). The K losses, however, can be attributed to the source material of the soil. This can be granitic and magmatic rocks that are rich in this element. Furthermore, it is necessary to consider that $\mathrm{K}$ is a monovalent element weakly retained by the $\mathrm{CEC}$ of the soil, making it easily leached (Ernani et al., 2007). The same can happens with $\mathrm{Na}$. The relatively smaller $\Delta \mathrm{P}$ values are mainly due to the low mobility of the element, causing most of the $\mathrm{P}$ to be retained in the soil, as discussed by Van Beek et al. (2009) who studied the pathways of phosphorus loss in three soil types under grazing.

The hierarchical cluster analysis (Figure 2) showed that variables had similar behaviour in both hillslopes. 
The responses to the process of $\mathrm{R}, \Delta \mathrm{S}$ and nutrient loss are inherent to each particular hillslope. This is confirmed by the separation of elements that are dependent on land use and coverage in each hillslope; group 1 in $\mathrm{H}_{\mathrm{D}}$ and group 4 in $\mathrm{H}_{\mathrm{F}}$. Sousa et al. (2012) also obtained similar results in the cluster analysis of overgrazed and exclusion areas. This result gives a strong indication that cluster analysis is an appropriate tool for checking the similarity of variables between hillslopes, and that this seems to capture the effect of both ground coverage and land-use on the variables analyzed.

Ten years of fallow in Caatinga were not enough to promote conclusive changes in soil and vegetation, although marked evolution could be verified, mainly relating to runoff and loss of soil and organic carbon. Similar results were obtained by Navarro-Hevia et al. (2014), who evaluated the historical evolution of the restoration of degraded lands in Saldaña, Spain. Authors concluded that the first ten years of intervention in this degraded region in Spain were enough to recover only $20 \%$ of the area. This small recovery rate should be taken into account in the development policies, especially in dry lands. This was not the case in the African savannah, whose dense woodlands decreased by $64 \%$ in less than two decades (Kalema et al., 2015).

\section{CONCLUSIONS}

Ten years of fallow in Caatinga biome reduced runoff, organic carbon and soil losses in the recovered hillslope in relation to the degraded slope. The reduction of organic carbon losses indicates increased carbon stock in areas of Caatinga. As for nutrients, the period of fallow was not enough to reduce losses. Organic carbon proved to be a good parameter to evaluate the loss of nutrients, as this variable showed to be correlated with nutrient loss in both hillslopes. Cluster analysis was sensitive to soil management as it captured the effect of ground cover and separated the variables of runoff, as well as soil and nutrient loss into similar groups for each hillslope (recovered and degraded).

\section{SUBMISSION STATUS}

Received: 26 aug., 2016

Accepted: 7 sept., 2016

\section{CORRESPONDENCE TO}

\section{Cicero Lima de Almeida}

Department of Agricultural Engineering, Universidade Federal do Ceará - UFC, Campus do Pici, Bloco 804, CEP 60450-760, Fortaleza, CE, Brazil e-mail: climaal@hotmail.com, cincerolima@yahoo.com.br

\section{REFERENCES}

American Public Health Association - APHA. Standard methods for the examination of water and wastewater. 21st ed. Washington; 2005.

Amorim LB, Salcedo IH, Pareyn FGC, Alvarez IA. Assessment of nutrient returns in a tropical dry forest after clear-cut without burning. Nutrient Cycling in Agroecosystems 2014; 100(3): 333-343. http://dx.doi. org/10.1007/s10705-014-9646-5.

Araújo ICS, Costa MCG. Biomass and nutrient accumulation pattern of leguminous tree seedlings grown on mine tailings amended with organic waste. Ecological Engineering 2013; 60: 254-260. http://dx.doi.org/10.1016/j. ecoleng.2013.07.016.

Brazier RE, Turnbull L, Wainwright J, Bol R. Carbon loss by water erosion in drylands: implications from a study of vegetation change in the south-west USA. Hydrological Processes 2014; 28(4): 2212-2222. http:// dx.doi.org/10.1002/hyp.9741.

Centro Nacional de Pesquisa de Solos - EMBRAPA. Manual de métodos de análise de solo. Rio de Janeiro: Embrapa Solos; 1997.

Costantini EAC, Branquinho C, Nunes A, Schwilch G, Stavi I, Valdecantos A et al. Soil indicators to assess the effectiveness of restoration strategies in dryland ecosystems. Solid Earth 2016; 7(2): 397-414. http://dx.doi.org/10.5194/ se-7-397-2016.

Döll P, Jiménez-Cisneros B, Oki T, Arnell NW, Benito G, Cogley JG et al. Integrating risks of climate change into water management. Hydrological Sciences Journal 2015; 60(1): 4-13. http://dx.doi.org/10.1080/02626667. 2014.967250 .

Ebeledike EU, Nwokedi GIC, Ndu OO, Okoye FBC, Ochiogu IS. Calcium and phosphorus contents of body parts of some domestic animals used as meat source in Nigeria. Asian Pacific Journal of Tropical Medicine 2010; 3(5): 395 398. http://dx.doi.org/10.1016/S1995-7645(10)60096-X.

El Kateb H, Zhang H, Zhang P, Mosandl R. Soil erosion and surface runoff on different vegetation covers and slope gradients: a field experiment in Southern Shaanxi Province, China. Catena 2013; 105: 1-10. http://dx.doi. org/10.1016/j.catena.2012.12.012. 
Ernani PR, Bayer C, Almeida JA, Cassol PC. Mobilidade vertical de cátions influenciada pelo método de aplicação de cloreto de potássio em solos com carga variável. Revista Brasileira de Ciencia do Solo 2007; 31(2): 393-402. http:// dx.doi.org/10.1590/S0100-06832007000200022.

Fernandes MRM, Matricardi EAT, Almeida AQ, Fernandes MM. Mudanças do uso e de cobertura da terra na região semiárida de Sergipe. Floresta e Ambiente 2015; 22(4): 472-482. http://dx.doi.org/10.1590/2179-8087.121514.

Freitas MASR, Andrade EM, Weber OB, Palácio HAQ, Ferreira TO. Bedload sediment and nutrient losses in agro-ecosystems of the Brazilian semiarid region. Nutrient Cycling in Agroecosystems 2013; 96(2-3): 203-213. http:// dx.doi.org/10.1007/s10705-013-9586-5.

Instituto Nacional de Meteorologia - INMET. Banco de Dados Meteorológicos para Ensino e Pesquisa - BDMEP [online]. Brasília, 2016 [cited 2016 aug 26]. Available from: http://www.inmet.gov.br/portal/index.php?r=bdmep/bdmep.

Kalema V. N., Witkowski E. T. F., Erasmus B. F. N., Mwavu E. N. The impacts of changes in land use on woodlands in an Equatorial African Savanna. Land Degradation and Development, 2015; 26(7): 632-641. http://dx.doi. org/10.1002/ldr.2279.

Kurz I, Coxon C, Tunney H, Ryan D. Effects of grassland management practices and environmental conditions on nutrient concentrations in overland flow. Journal of Hydrology (Amsterdam) 2005; 304(1-4): 35-50. http:// dx.doi.org/10.1016/j.jhydrol.2004.07.022.

Lessa ACR, Madari BE, Paredes DS, Boddey RM, Urquiaga U, Jantalia CP et al. Bovine urine and dung deposited on Brazilian savannah pastures contribute differently to direct and indirect soil nitrous oxide emissions. Agriculture, Ecosystems \& Environment 2014; 190: 104-111. http:// dx.doi.org/10.1016/j.agee.2014.01.010.

Li XR, Jia XH, Dong GR. Influence of desertification on vegetation pattern variations in the cold semi-arid grasslands of Qinghai-Tibet Plateau, North-west China. Journal of Arid Environments 2006; 64(3): 505-522. http:// dx.doi.org/10.1016/j.jaridenv.2005.06.011.

Manzano MG, Návar JH. Processes of desertification by goats overgrazing in the Tamaulipanthorn scrub (matorral) in north-eastern Mexico. Journal of Arid Environments 2000; 44(1): 1-17. http://dx.doi.org/10.1006/jare.1999.0577.

Medeiros PHA, Araújo JC. Temporal variability of rainfall in a semiarid environment in Brazil and its effect on sediment transport processes. Journal of Soils and Sediments 2014; 14: 1216-1223. http://dx.doi.org/10.1007/ s11368-013-0809-9.

Mekuria W, Aynekulu E. Exclosure land management for restoration of the soils indegraded communal grazing lands in Northern Ethiopia. Land Degradation \& Development 2013; 24(6): 528-538. http://dx.doi.org/10.1002/ldr.1146.
Menezes RSC, Sampaio EV, Giongo V, Pérez-Marin A. Biogeochemical cycling in terrestrial ecosystems of the Caatinga Biome. Brazilian Journal of Biology = Revista Brasileira de Biologia 2012;72(3, Suppl): 643653. PMid:23011295. http://dx.doi.org/10.1590/S151969842012000400004.

Navarro-Hevia J, Araújo JC, Manso JM. Assessment of 80 years of ancient-badlands restoration in Saldaña, Spain. Earth Surface Processes and Landforms 2014; 39(12): 1563-1575. http://dx.doi.org/10.1002/esp.3541.

Nunes B, Bennett D, Marques S Jr. Sustainable agricultural production: an investigation in Brazilian semi-arid livestock farms. Journal of Cleaner Production 2014; 64: 414-425. http://dx.doi.org/10.1016/j.jclepro.2013.07.023.

Palacio RG, Bisigato AJ, Bouza BJ. Soil erosion in three grazed plant communities in Northeastern Patagonia. Land Degradation \& Development 2014; 25(6): 594-603. http://dx.doi.org/10.1002/ldr.2289.

Príncipe A, Nunes A, Pinho P, Rosário L, Correia $\mathrm{O}$, Branquinho C. Modeling the long-term natural regeneration potential of woodlands in semi-arid regions to guide restoration efforts. European Journal of Forest Research 2014; 133: 757-767. http://dx.doi.org/10.1007/ s10342-014-0787-5.

Sath K, Pauly T, Holtenius K. Mineral balance of Cambodian cattle based on their faecal and urinary excretion. Journal of Animal and Veterinary Advances 2012; 11(22): 4221-4225.

Silva AML, Lopes SF, Vitorio LAP, Santiago RR, Mattos EA, Trovão DMBM. Plant functional groups of species in semiarid ecosystems in Brazil: wood basic density and SLA as an ecological indicator. Brazilian Journal of Botany 2014; 37(3): 229-237. http://dx.doi.org/10.1007/ s40415-014-0063-4.

Sousa FP, Ferreira TO, Mendonca ES, Romero RE, Oliveira JGB. Carbon and nitrogen in degraded Brazilian semi-arid soils undergoing desertification. Agriculture, Ecosystems \& Environment 2012; 148: 11-21. http://dx.doi.org/10.1016/j. agee.2011.11.009.

Stanchi S, Falsone G, Bonifacio E. Soil aggregation, erodibility, and erosion rates in mountain soils (NW Alps, Italy). Solid Earth 2016; 6(2): 403-414. http://dx.doi. org/10.5194/se-6-403-2015.

Tang FK, Cui M, Lu Q, Liu YG, Guo HY, Zhou JX. Effects of vegetation restoration on the aggregate stability and distribution of aggregate-associated organic carbon in a typical karst gorge region. Solid Earth 2016; 7(1): 141-151. http://dx.doi.org/10.5194/se-7-141-2016.

Trabaquini K, Formaggio AR, Galvão LS. Changes in physical properties of soils with land use time in the Brazilian savanna environment. Land Degradation and Development 2015; 26(4): 397-408. http://dx.doi. org/10.1002/ldr.2222. 
Van Beek CL, Van der Salm C, Plette ACC, Van de Weerd $H$. Nutrient loss pathways from grazed grasslands and the effects of decreasing inputs: experimental results for three soil types. Nutrient Cycling in Agroecosystems 2009; 83: 99-110. http://dx.doi.org/10.1007/s10705-008-9205-z.

Wischmeier WH, Smith DD. Predicting rainfall erosion losses: a guide to conservation planning. Washington: USDA, 1978. 58 p. Agriculture Handbook, n. 537.
Yeomans JC, Bremner JM. A rapid and precise method for routine determination of organic carbon sin soil. Communications in Soil Science and Plant Analysis 1988; 19(13): 1467-1476. http://dx.doi.org/10.1080/00103628809368027.

Zhao H, Huang G, Ma J, Li Y, Tang L. Decomposition of aboveground and root litter for three desert herbs: mass loss and dynamics of mineral nutrients. Biology and Fertility of Soils 2014; 50(5): 745-753. http://dx.doi. org/10.1007/s00374-013-0892-5. 